\title{
ARSENIC CONTENT IN ARABLE LAND OF THE ZĄBKOWICE DISTRICT
}

\author{
Jarosław KASZUBKIEWICZ ${ }^{1}$, Ewa PORA, Dorota KAWAŁKO, \\ Paweł JEZIERSKI \\ Wrocław University of Environmental and Life Sciences, \\ The Faculty of Life Sciences and Technology, Wrocław, Poland
}

\begin{abstract}
The aim of this study was to determine the content of arsenic in soils used for agriculture in the Ząbkowicki district. The content of arsenic in collected soil samples ranged $1.1-569.5 \mathrm{mg} \cdot \mathrm{kg}^{-1}$. The standard for arable lands of Group B has been exceeded in 24 out of 231 test points. The highest concentrations occurred in the Złoty Stok commune. This is due to the output of arsenic and gold in this area. Exceeding the standard also occurred in neighboring communes: Kamieniec Ząbkowicki and Ziębice. This is due to the blowing and washing pollutions form the source of contamination, the arsenic mines in the Złoty Stok commune.
\end{abstract}

Keywords: arsenic, arable land, Ząbkowicki district

\section{INTRODUCTION}

Arsenic is a highly toxic element [1,11], causing cancer of the skin and internal organs $[20,23]$. Its toxicity depends primarily on the concentration and forms of occurrence [19]. The absorption of this element can occur by ingestion, inhalation and through the skin [6]. Exceeding the limit values for arsenic in soil causes a small number of trees and bushes, discoloration, stunting, and even deformation of the whole plant [4]. Typical contents of arsenic in soil is in the range of 0.2 to $16 \mathrm{mg} \cdot \mathrm{kg}^{-1}$. The highest concentrations found in soils with a high

\footnotetext{
${ }^{1}$ Corresponding author: Wrocław University of Environmental and Life Sciences, The Faculty of Life Sciences and Technology, Grunwaldzka 53, 50-375 Wrocław, Poland; e-mail: jaroslaw.kaszubkiewicz@up.wroc.pl, tel. +48713205603
} 
content of clay fraction and organic soils [6]. The performance of arsenic in soil is usually associated with the weathering of rocks. Anthropogenic activities such as mining, metallurgy of nonferrous metals, coal burning, or use of pesticides containing arsenic can cause increased concentration of this element in the water and soil [1]. Currently, high concentrations of arsenic were recorded in 21 countries, including Poland [15]. The Ząbkowicki district has the oldest mining and metallurgical center in Poland - Złoty Stok. The last arsenic ore mine in this area was closed in 1961[14]. The aim of this study was to analyze the content of arsenic in soils used for agriculture in the Ząbkowicki district.

\section{DESCRIPTION OF THE RESEARCH OBJECTS}

The Ząbkowicki district is located in south-western Poland, in the Dolny Śląsk province. It is located at the foothills of the Sudeten and covers $802 \mathrm{~km}^{2}$ [12]. In the complex of the district there are four urban-villages (Bardo, Ząbkowice Śląskie, Ziębice and Złoty Stok) and three village communes (Ciepłowody, Kamieniec Ząbkowicki and Stoszowice).



Fig. 1. Location of soil sampling points

Mild weather conditions [5], and the presence of very good soils (Ciepłowody and Zabkowice Śląskie) cause that a larger area of the district is used for agriculture (Fig. 2) [2]. Arable land in the Ząbkowicki district is formed in a 
vast majority of loess and silt of water origin. The contribution of these formations in the total area of arable land in the district is $44.1 \%$, and in the communes ranges from $5.1 \%$ in Bardo, to $96.2 \%$ in Ciepłowody. A similar share of the total arable land in the district has loam, 41.9\%. However, in the communes, loams occupy arable lands from $3.1 \%$ in Ciepłowody to $98.4 \%$ in Złoty Stok. Water origin silty loams are of a certain significance. Their share in the total area of the district is $7.8 \%$, while in the communes amounted from $1.6 \%$ in Złoty Stok, to $17.1 \%$ in Ziębice. Sandy soils in the district occupy $5.2 \%$ of the arable land. In the communes it is an area from $0.1 \%$ in Cieplice to $11.0 \%$ in Kamieniec Ząbkowicki.

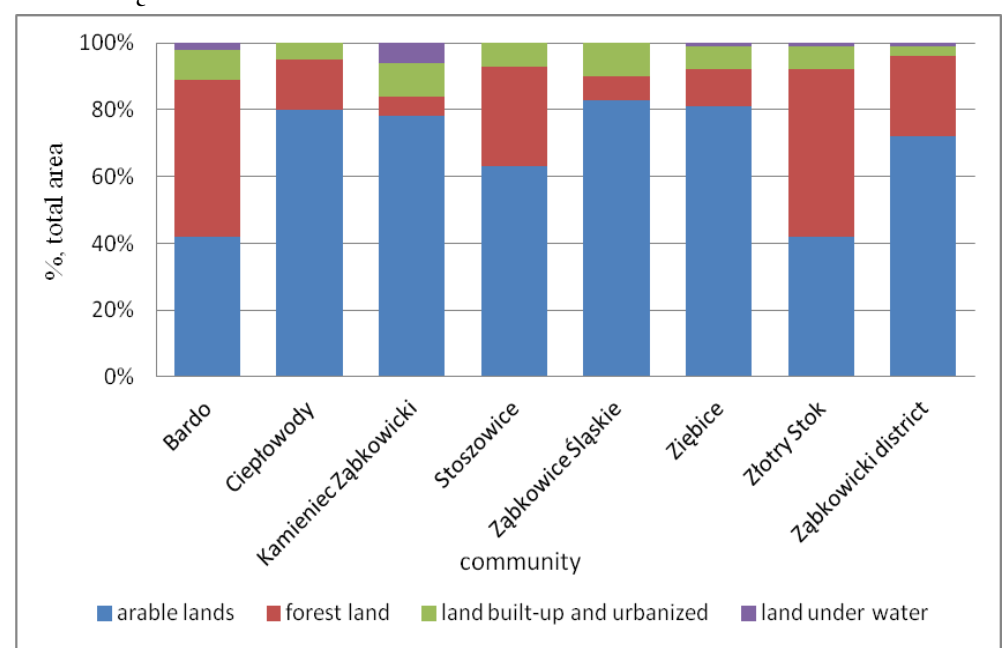

Fig. 2. The structure of land use in the communes of the Ząbkowicki district

There are tens of hectares of clay soils in small enclaves in the four communes where the surface varies from $0.1 \%$ (12ha) in the commune of Ząbkowice Śląskie, to $21.2 \%$ (330ha) in Ziębice.

\section{RESEARCH METHODS}

The study was conducted on arable land of 7 communes and 2 cities in the Ząbkowicki district. For the analysis 231 samples were collected (Fig.1). The summary of sampling sites is shown in table 1. Material for the study was collected from a depth of $0-30 \mathrm{~cm}$ of the few places directly adjacent to the point of the test (located at a distance of less than $5 \mathrm{~m}$ ). In order to control the depth, the samples were taken with the use of a soil core sampler. The samples were mixed directly in the field, and possible excess was removed. 
Table. 1 Summary of soil sampling sites

\begin{tabular}{|c|l|c|}
\hline Community & \multicolumn{1}{|c|}{ Ambit } & $\begin{array}{c}\text { Number of } \\
\text { samples }\end{array}$ \\
\hline Ząbkowice & $\begin{array}{l}\text { Bobolice, Brodziszów, Braszowice, Grochowiska, } \\
\text { Jaworek, Koziniec, Kluczowa, Olbrachcice, } \\
\text { Pawłowice, Sieroszów, Stolec, Strąkowa, } \\
\text { Sulisławice, Szklary, Tarnów, Zawrócona }\end{array}$ & 44 \\
\hline Ząbkowice city & Ząkowice city, Sadłów & 3 \\
\hline Stoszowice & $\begin{array}{l}\text { Budzów, Grodziszcze, Jemna, Lutomierz, } \\
\text { Przedborowa, Różana, Rudnica, Stoszowice }\end{array}$ & 22 \\
\hline Kamieniec & $\begin{array}{l}\text { Byczeń, Kamieniec Ząbkowicki, Sławęcin, } \\
\text { Sosnowa, Topola, Starczów, Doboszowice, } \\
\text { Pomianów Górny, Mrokocin, Chałupki }\end{array}$ & 23 \\
\hline Złoty Stok & Błotnica, Płonica, Mąkolno, Chwalisław, Laski & 3 \\
\hline Złoty Stok city & Złoty Stok city & 39 \\
\hline Ciepłowody & $\begin{array}{l}\text { Muszkowice, Czesławie, Stary Henryków, } \\
\text { Wilamowice, Targowica, Janówka, Jakubów, } \\
\text { Cienkowice, Baldwinowice, Piotrowie Polskie, } \\
\text { Karczowice, Kobyla Głowa, Koźmice, Tomice, } \\
\text { Dobrzenice, Brochocin, Ciepłowody }\end{array}$ & 22 \\
\hline Bardo & $\begin{array}{l}\text { Brukalice, Wigańcice, Kalinowice Dolne, } \\
\text { Kalinowice Górne, Pomianów Dolny, Lubnów, } \\
\text { Głęboka, Niedźwiedź, Biernacice, Służejów, } \\
\text { Niedźwiednik, Starczówek, Osina Wielka, Osina } \\
\text { Mała, Dębowiec, Nowina, Bożnowice, Raczyce, } \\
\text { Witostowice, Wadochowice, Henryków, Nowy } \\
\text { Dwór, Krzelków, Czerńczyce, Rososznica }\end{array}$ & $\begin{array}{l}\text { Opolnica, Dębowina, Laskówka, Dzbanów, } \\
\text { Przyłęk, Potworów, Grochowa, Brzeźnica }\end{array}$ \\
\hline
\end{tabular}

For laboratory tests, soil material was dried at room temperature. In determining the proportion of a particle size of soil skeleton, the samples were sieved through sieves with a mesh diameter of $2 \mathrm{~mm}$ and $1 \mathrm{~mm}$. Fine earth separated in this way $(<1 \mathrm{~mm})$ was subjected to further analysis. Soil research included: granulometric composition by the aerometric-sieve method, soil reaction ( $\mathrm{pH}$ in distilled water and $1 \mathrm{M} \mathrm{KCl} \mathrm{-} \mathrm{by} \mathrm{potentiometry),} \mathrm{organic} \mathrm{carbon} \mathrm{content} \mathrm{by} \mathrm{the}$ Tiurin method. The determination of arsenic was made by GFAAS after mineralization in aqua regia. For the assessment of the correctness of the determinations, certified reference materials and internal standards were used. Maps were prepared in the scale of 1:50000. In the development of maps Inverse Distance interpolation type Weighting (IDW) was used. 


\section{RESULTS}

Table 2 summarizes the median content of each granulometric fraction in arable soils for each community of the Zabkowicki district. Granulometric composition is shown in Fig. 3. The analyzed soils showed little soil skeleton (more than $80 \%$ of the analyzed soils samples was less than $1 \%$ ), so this fraction has been omitted.

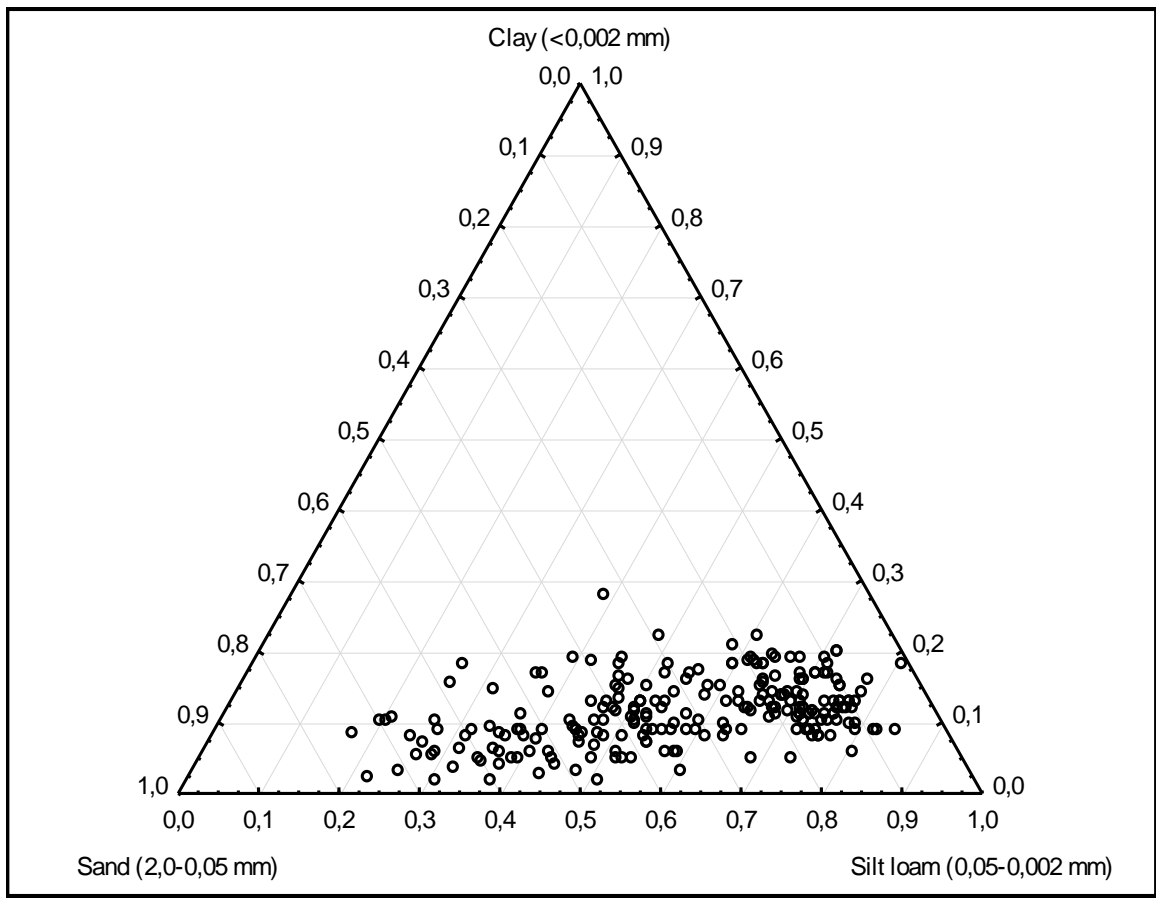

Fig. 3. Granulometric composition of soils from the area of the communities of the Ząbkowicki district

Among the collected soil samples silt loam dominated (169 samples). In a smaller amount there was loam (63 attempts). The fractions of silt loam (0.05$0.002 \mathrm{~mm})$ and sand $(2.0-0.05 \mathrm{~mm})$ have a largest share in granulometric composition of the examined soils. Clay fraction occurred in the least number of samples.

The $\mathrm{pH}$ values of soil samples, measured in $1 \mathrm{M} \mathrm{KCl}$ solution, ranged in 3.5 - 7.6. The median for all the soil samples was 5.2. In terms of the reaction classification, 52 samples were very acidic, 101- acidic, 62 - slightly acidic, 10 - neutral, and 6 - alkaline. 
Table. 2. Particle size of the tested soil samples

\begin{tabular}{|c|c|c|c|}
\hline \multirow{2}{*}{ Community } & \multicolumn{3}{|c|}{ Median of fraction content, \% } \\
\cline { 2 - 4 } & $2.0-0.05 \mathrm{~mm}$ & $0.05-0.002 \mathrm{~mm}$ & $<0.002 \mathrm{~mm}$ \\
\hline Ciepłowody & 11.0 & 74.0 & 14.0 \\
\hline Ziębice & 35.0 & 54.0 & 10.0 \\
\hline Złoty Stok & 51.0 & 45.0 & 7.3 \\
\hline Bardo & 36.5 & 51.0 & 11.5 \\
\hline Kamieniec Ząbkowicki & 46.0 & 44.5 & 9.8 \\
\hline Ząbkowice Śląskie & 18.3 & 68.4 & 10.9 \\
\hline Stoszowice & 37.5 & 49.7 & 11.8 \\
\hline
\end{tabular}

The $\mathrm{pH}$ median values for individual communes and the percentage share of soil reaction are shown in Tab.3. Organic carbon content ranged from $0.27 \%$ (Ząbkowice) to $5.37 \%$ (Bardo), with an average content of $1.12 \%$. The average content of humus was $1.93 \%$ (range $0.62-9.26 \%$ ).

Table. 3. Reaction and $\mathrm{pH}$ of soil tested samples

\begin{tabular}{|c|c|c|c|c|c|c|c|}
\hline \multirow{2}{*}{ Commune } & \multicolumn{5}{|c|}{ participation of soils , } & \multicolumn{2}{c|}{$\mathrm{pH} 1 \mathrm{M} \mathrm{KCL}$} \\
\cline { 2 - 8 } & $\begin{array}{c}\text { very } \\
\text { acidic }\end{array}$ & acidic & $\begin{array}{c}\text { slightly } \\
\text { acidic }\end{array}$ & neutral & alkaline & range & median \\
\hline Ciepłowody & 17.9 & 48.7 & 25.6 & 5.1 & 2.6 & $3.5-7.2$ & 5.4 \\
\hline Ziębice & 26.2 & 37.7 & 23.0 & 6.6 & 6.6 & $3.5-7.5$ & 5.2 \\
\hline Złoty Stok & 35.3 & 47.1 & 11.8 & 5.9 & 0.0 & $3.6-7.5$ & 5.1 \\
\hline Bardo & 27.3 & 54.5 & 18.2 & 0.0 & 0.0 & $3.6-7.5$ & 5.1 \\
\hline $\begin{array}{c}\text { Kamieniec } \\
\text { Ząbkowicki }\end{array}$ & 30.4 & 34.8 & 30.4 & 4.3 & 0.0 & $3.6-7.6$ & 4.8 \\
\hline $\begin{array}{c}\text { Ząbkowice } \\
\text { Śląskie }\end{array}$ & 8.5 & 46.8 & 38.3 & 4.3 & 2.1 & $3.8-7.5$ & 5.4 \\
\hline Stoszowice & 27.3 & 40.9 & 31.8 & 0.0 & 0.0 & $3.8-6.5$ & 5.2 \\
\hline
\end{tabular}

Acceptable arsenic content, defined for agricultural land in the Regulation of the Minister of Environment of 9 September 2002 on the soil quality standards, for lands from the B Group is $20 \mathrm{mg} \cdot \mathrm{kg}^{-1}$. The content of arsenic in the collected soil samples ranged $1.1-569.5 \mathrm{mg} \cdot \mathrm{kg}^{-1}$. The limit value was exceeded in 24 out of 231 test points. The average content of arsenic in the studied samples was $32.35 \mathrm{mg} \cdot \mathrm{kg}^{-1}$, and the median $20.45 \mathrm{mg} \cdot \mathrm{kg}^{-1}$.

Fig. 4 shows the total arsenic content in agricultural soils in the Zabkowicki district. The standard was exceeded in three communes: Kamieniec Ząbkowicki (8 samples of 23 - range of exceeding $20.5-46.4 \mathrm{mg} \cdot \mathrm{kg}^{-1}$ ), Złoty Stok (16 samples of 17 - range of exceeding $22.0-569.45 \mathrm{mg} \cdot \mathrm{kg}^{-1}$ ), and Ziębice (1 trial of $\left.61.0-25.1 \mathrm{mg} \cdot \mathrm{kg}^{-1}\right)$. The elaborated map shows that maximum levels of arsenic 
were exceeded only in the southern part of the Ząbkowicki district. The range of arsenic contamination of soil is $12 \mathrm{~km}$ from the source, which was the mine in Złoty Stok. Other areas are not contaminated with As.

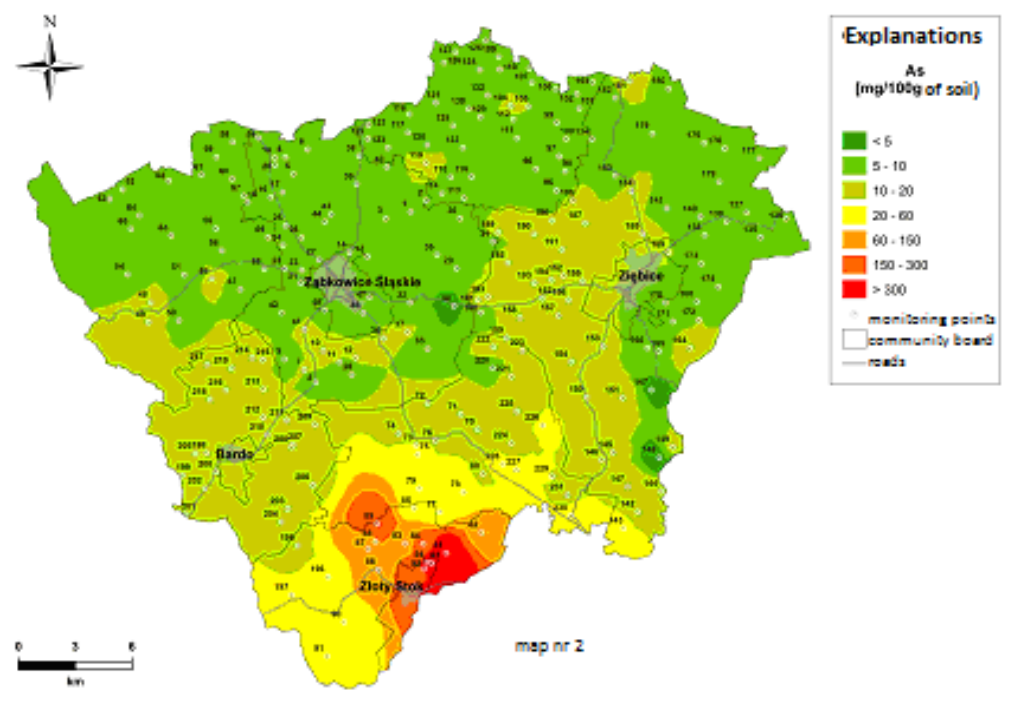

Fig. 4. Spatial distribution of total arsenic in soils of the Ząbkowicki district agricultural lands

In addition to the standards set out in the Regulation, multi-step evaluation of arsenic in the soil can be made on the basis of the geoaccumulation index [16] according to the equation:

$$
\mathrm{I}_{\mathrm{geo}}=\log _{2}\left(\mathrm{C}_{\mathrm{As}} / 1,5 \mathrm{~B}_{\mathrm{As}}\right)
$$

where: $\mathrm{C}_{\mathrm{AS}}$ is the measured concentration of arsenic

$\mathrm{B}_{\mathrm{AS}}$ is the geochemical background value

the constant 1.5 allows us to analyze natural fluctuations in the content of a given substance in the environment and very small anthropogenic influences.

Assessment is based on a comparison of current levels of heavy metals in the geochemical background (element contents in parent rock) [13]. Background level for arsenic is taken as $9.02 \mathrm{mg} \cdot \mathrm{kg}^{-1}$. This is the average concentration of arsenic in soils of the 9 districts of the Sudeten and the foothills of Sudetenland [10]. 
Table. 3 Determination of arsenic accumulation classes in communes of the Ząbkowicki district based on geoaccumulation index

\begin{tabular}{|c|c|c|c|c|c|c|c|}
\hline \multirow{2}{*}{ Commune } & \multicolumn{7}{|c|}{ Classes of index } \\
\cline { 2 - 9 } & $0 *$ & 1 & 2 & 3 & 4 & 5 & 6 \\
\hline Ciepłowody & 38 & 1 & - & - & - & - & - \\
\hline Ziębice & 53 & 8 & - & - & - & - & - \\
\hline Złoty Stok & 0 & 4 & 2 & 3 & 3 & 3 & 2 \\
\hline Bardo & 10 & 12 & - & - & - & - & \\
\hline $\begin{array}{c}\text { Kamieniec } \\
\text { Ząbkowicki }\end{array}$ & 8 & 10 & 5 & - & - & - & - \\
\hline $\begin{array}{c}\text { Ząbkowice } \\
\text { Śląkie }\end{array}$ & 47 & - & - & - & - & - & - \\
\hline Stoszowice & 21 & 1 & - & - & - & - & - \\
\hline
\end{tabular}
*Class 0- practically uncontaminated, 1- uncontaminated to moderately contaminated,
2- moderately contaminated, 3- moderately to heavily contaminated, 4- heavily contaminated,
5- heavily to extremely contaminated, 6- extremely contaminated.

\section{DISCUSSION}

Arsenic is used in many industries: semiconductor industry, pesticides production, materials for wood preservation, metal alloys, glass, pigments and pharmaceuticals [3]. The presence of this metal can have a natural source (related to parent rock) or anthropogenic (fossil fuel combustion, smelting $\mathrm{Cu}$, $\mathrm{Pb}$, nickel ore, as well as an improper use or overuse of pesticides). Geological risks related to the soil load of heavy metal are considered lower than anthropogenic pollution [21]. Soil pollution with heavy metals in Lower Silesia is primarily associated with the mining and processing of metal ores (current or historical), and the proximity of urban areas and post [8]. A study done by the Plak [18] show that the total arsenic content in soils of Lublin agglomeration ranged from $0.42-19.62 \mathrm{mg} \cdot \mathrm{kg}^{-1}$. Arsenic concentration in soils of the Ząbkowicki district is much higher: $1.1-569.5 \mathrm{mg} \cdot \mathrm{kg}^{-1}$. From 231 examined soil samples, 25 exceeded the legal limit of arsenic for agricultural land. They were the soil of the three communes: Złoty Stok, Kamieniec Ząbkowicki and Ziębice. In the other communes this metal content was within the standard. The largest accumulation of arsenic in soils $\left(569.5 \mathrm{mg} \cdot \mathrm{kg}^{-1}\right)$, was found in a sample from the Złoty Stok (Fig. 5). This is due to the presence in this area of arsenic and gold deposits that have been exploited since the ' 90 of thirteenth century [14]. Similar results were obtained by Kicińska[11], who examined the soil adjacent to the Mining and Metallurgical Bets in the Bukowno region. She meant the arsenic content in the whole soil profile. 
The largest concentration of metal appeared in the surface layer of soil (1900 $\mathrm{mg} \cdot \mathrm{kg}^{-1}$ ), and at a depth of $30 \mathrm{~cm}$ arsenic content was four times less: 467 $\mathrm{mg} \cdot \mathrm{kg}^{-1}$. In the commune of Kamieniec Ząbkowicki, adjacent to Złoty Stok, $34.0 \%$ of the samples exceeded the limit values of arsenic. Its highest concentration was $46.4 \mathrm{mg} \cdot \mathrm{kg}^{-1}$. In this area, there are no industrial centers. According Niedzielski [17] soils which are not in contact with the anthropogenic sources of pollution show that the content of this element does not correspond to the background. This is related to the widespread pollution. Moreover, all communes in the Ząbkowicki district have predominantly acidic soils, which increase the mobility of metallic elements [9]. Exceeding the standards may be associated with inappropriate agricultural practices, the bedrock [24] or soils rich in organic matter [7]. Arsenic mobility is also connected with the presence of silicate minerals and hydroxides $\mathrm{Fe}, \mathrm{Al}$ and $\mathrm{Mn}$ [22]. In the Ząbkowice commune only one trial (on 44) exceeded the standard. Exceeding was low $\left(5.1 \mathrm{mg} \cdot \mathrm{kg}^{-1}\right)$.

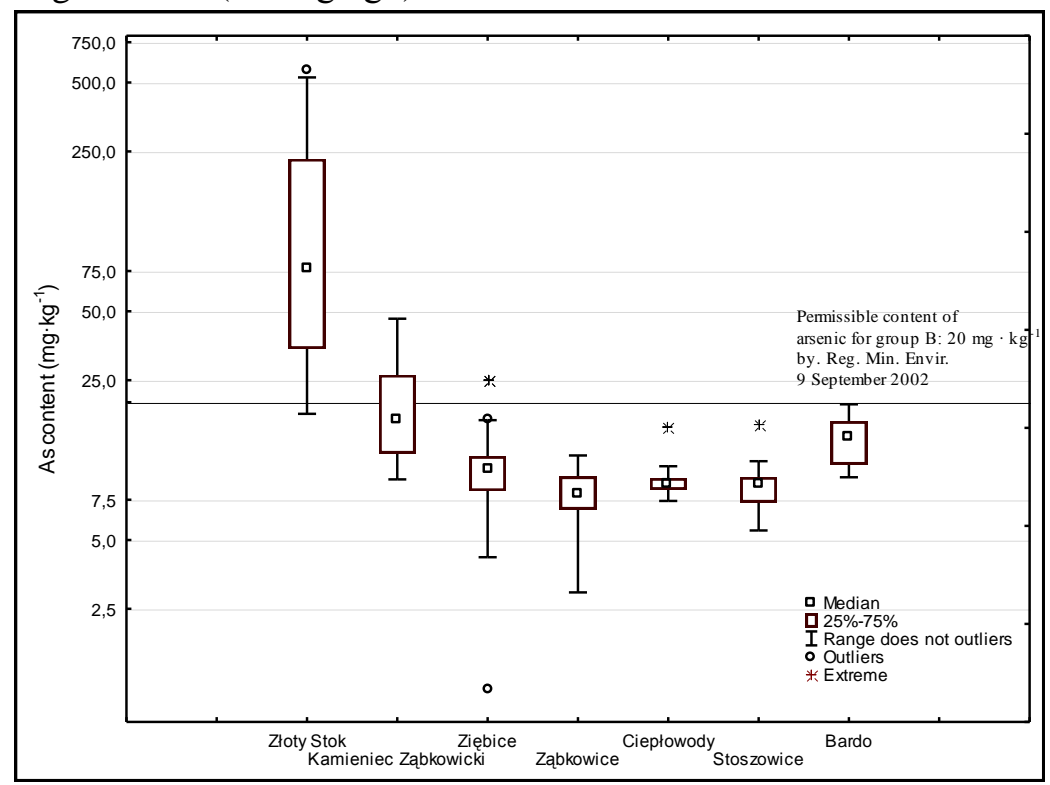

Fig. 5. Arsenic content in arable land of the Ząbkowicki district

The reason for this phenomenon is the same as in the case of Kamieniec Ząbkowicki. The analysis of the arsenic concentration in soils on the basis of geoaccumulation index (tab. 3, Fig.6) shows that the soils are the cleanest in the commune of Ząbkowice Slaskie (47 samples practically uncontaminated). In the communes of Cieplice, Ziębice, Bardo, Stoszowice soils are uncontaminated to moderately contaminated. Moderately contaminated soils are located in 
Kamieniec Ząbkowicki while in Złoty Stok there are all classes of pollution (including class 6 , which is extremely contaminated soils).



Fig. 6. Geoaccumulation index in communes of Ząbkowicki district

\section{CONCLUSIONS}

1. In terms of the geoaccumulation index, the soils in Złoty Stok commune are extremely contaminated.

2. Pollution appears even in the area of $12 \mathrm{~km}$ away from the source of contamination, which is the mine in Złoty Stok.

3. Soils contaminated with arsenic occur in the southern part of the Zabkowicki district. Exceeding the standards related to the area of arsenic and gold mining is conducted in this area.

4. In the Ząbkowicki district there are mostly very acidic, acidic and slightly acidic soils. This reflects the nature of the host rock. It will also contribute to increase the mobility of arsenic in the soil.

\section{ADDITIONAL INFORMATION}

The study was performed on the basis of Silesian Arable Land Protection Fund. 


\section{REFERENCES}

1. Dahal B.M., Fuerhacker M., Mentler A., Karki K.B., Shrestha R.R., Blum W.E.H.: Arsenic contamination of soils and agricultural plants through irrigation water in Nepal, Environmental Pollution, 155 (2008) 157-163.

2. Data from Wydział Geodezji Katastru i Nieruchomości Starostwa Powiatowego w Ząbkowicach Śląskich z 2011 roku.

3. DeSesso J.M., Jacobson C.F., Scialli A.R., Farr C.H., Holson J.F.: An assessment of the developmental toxicity of inorganic arsenic, Reproductive Toxicology, 12, 4 (1998) 385-433.

4. Dziubek J.: Removal of Arsenic compounds from industrial wastewater, Ochrona Środowiska, 28,4 (2006) 41-44.

5. Gumiński: Próba wydzielenia dzielnic rolniczo-klimatycznych w Polsce., Przegl. Meteo. i Hydrol., 1948.

6. Kabata-Pendias A.: Biogeochemia pierwiastków śladowych, Wyd. Nauk. PWN, 1999.

7. Kabata-Pendias A.: Trace elements from soil to human, Geophysical Research Abstracts, 9 (2007) 11054.

8. Karczewska A., Kabała C.: The soils polluted with heavy metals and arsenic in Lover Silesia - the need and methods of reclamation, Zeszyty Naukowe Uniwersytetu Przyrodniczego we Wrocławiu, Rolnictwo XCVI, 576 (2010) 59-79.

9. Karczewska A.: Perspektywy zastosowania fitoremediacji $w$ rekultywacji gleb zanieczyszczonych metalami ciężkimi, Ochrona Środowiska i Zasobów Naturalnych, 25/26 (2003) 27-54.

10. Kaszubkiewicz J., Dembowski M., Dembowski M., Jegierski P., Kawałko D., Tasz W.: Stan gleb użytkowanych rolniczo na obszarze Sudetów i Przedgórza Sudeckiego, Wrocław, Wyd. UP Wrocław, 2011.

11. Kicińska A.: Arsenic and thallium in soils and plants in the Bukowno area, Ochrona Środowiska i Zasobów Naturalnych, 40 (2009) 199-208.

12. Kondracki J.: Geografia regionalna Polski, Warszawa, Wyd. Nauk. PWN, 1998.

13. Loska K., Wiechuła D., Korus I.: Metal contamination of farming soils affected by industry, Environment International, 30 (2004) 159-165.

14. Madziarz M., Sztuk H.: Exploration of old mining positions at lower Silesia Region, Prace Naukowe Instytutu Górnictwa Politechniki Wrocławskiej, 111 (2005) 163-172.

15. Mohan D., Pittman C.U.: Arsenic removal from water/wastewater using adsorbents-a critical review, Journal of Hazardous Materials, 142 (2007) $1-53$. 
16. Müller G.: Die Schwermetallbelastung der Sedimenten des Neckars und Seiner Nebenflüsse, Chemiker-Zeitung, 6 (1981) 157- 64.

17. Niedzielski P., Siepak M., Siepak J.: Occurrence and contents of arsenic, antimony and selenium in waters and other elements of the environmental, Środkowo-Pomorskie Towarzystwo Naukowe Ochrony Środowiska, 317341.

18. Plak A.: Czynniki ksztattujace zawartość $i$ formy arsenu $w$ glebach aglomeracji lubelskiej, Rozprawy i Monografie (3), Lublin, 2007.

19. Rahman M. A., Hasegawa H., Lim R. P.: Bioaccumulation, biotransformation and thropic transfer of arsenic in the aquatic foodchain, Environmental Research, 116 (2012) 118-135.

20. Sińczuk-Walczak H.: Nervous system disorders induced by occupational exposure to arsenic and its inorganic compounds: a literature review, Medycyna Pracy, 60(6) (2009) 519-522.

21. Skála J., Vácha R., Čechmánková J.: Evaluation of arsenic occurrence in agricultural soils of the Bohemian Forest region, Silva Gabreta, 17(2-3) (2011) 55-67.

22. Szakova J., Tlusto P., Goessler W., Frkova Z., Najmanova J.: Mobility of arsenic and its compounds in soil and soil solution: the effect of soil pretreatment and extraction methods, Journal of Hazardous Materials, 172 (2009) 1244-1251.

23. Tapio S., Grosche B.: Arsenic in the aetiology of cancer, Mutation Research, 612 (2006) 215-246.

24. Wang S., Mulligan C.N.: Occurrence of arsenic contamination in Canada: sources, behavior and distribution, Science of the Total Environmental, 366 (2006) 701-721.

\section{ZAWARTOŚĆ ARSENU W GRUNTACH ORNYCH POWIATU ZĄBKOWICKIEGO}

\section{Streszczenie}

Celem publikacji było określenie zawartości arsenu w glebach wykorzystywanych rolniczo w powiecie ząbkowickim. Zawartość arsenu w pobranych próbach gleb mieściła się $\mathrm{w}$ granicach 1,1-569,5 $\mathrm{mg} \cdot \mathrm{kg}^{-1}$. Przekroczenie normy zawartości arsenu w gruntach ornych, określone w Rozporządzeniu, występuje w południowej części powiatu. Wartość dopuszczalna została przekroczona w 24 spośród 231 badanych punktów. Największa koncentracja tego pierwiastka wystapiła $\mathrm{w}$ gminie Złoty Stok. Związane jest to $\mathrm{z}$ ekspolatacją na tym terenie rud arsenu i złota. Przekroczenie dopuszczalnej zawartości wystąiło również $\mathrm{w}$ sąsiednim Kamieńcu Ząbkowickim oraz $\mathrm{w}$ Ziębicach. Jest to 
wynikiem występowania na tym terenie gleb kwaśnych, które zwiększają mobilność metali ciężkich.

Słowa kluczowe: $\quad$ arsen, grunty orne, powiat Ząbkowicki

Editor received the manuscript: 05.04.2013 